\title{
COMPARATIVE CHARACTERISTICS OF BIOLOGICAL AGE AND RATE OF AG- ING OF INTERNALLY DISPLACED AND LOCAL STUDENTS
}

\author{
Z. Boiarska, O. Dotsenko
}

\begin{abstract}
Мета дослідження - дослідити біологічний вік і темп старіння студентів, які мають статус внутрішньо переміщених осіб через 2-4 роки після евакуації з непідконтрольних територій з метою визначення провідних факторів старіння для подальшої розробки профілактичних заходів.

Матеріали і методи дослідження: ми досліджували 106 студентів Донецького національного університету імені Василя Стуса. Біологічний вік студентів визначався за методом Володимира Войтенка.

Результати дослідження: встановлено, щяо біологічний вік переселених студентів (чоловіки) у середньому становить 41,3 року (паспортний вік - 21,8 років), щзо на 89,4\% вище, ніж календарний вік. При обстеженні студентів того ж хронологічного віку, які постійно проживають у місті Вінниця, встановлено, щзо їх біологічний вік становить 37,6 років (паспортний вік - 20,5), щуо на 83,4 \% вище, ніж календарний вік. Біологічний вік дівчат-переселенців збільшився до 25,8 років (паспортний вік - 20 років), щчо на $29 \%$ вище, ніж календарний вік. Біологічний вік дівчат, які постійно проживають у Вінниці складає 29,2 роки (паспортний вік - 20 років), щчо на 46 \% вище, ніж календарний вік. При дослідженні темпів старіння студентів встановлено, що близько половини мають різко прискорені темпи старіння. При дослідженні темпів старіння студенток встановлено, щзо лише 12 \% має різко прискорений темп старіння. Крім того, у внутрішньо переміщених студенток (60,6\%) темп старіння знаходиться в межах норми.

Висновки: біологічний вік та темпи старіння студентів різко прискорені, причому істотно не відрізняються у переселенців та у місиевих студентів. Біологічний вік та темп старіння студенток прогресує не так швидко, студентки-переселенці мають показники, які знаходяться в межах норми для популяції Ключові слова: старіння, біологічний вік, паспортний вік, календарний вік, темпи старіння, передчасне старіння, статичне балансування, самооцінка
\end{abstract}

\section{Introduction}

According to the Ministry of Social Policy of Ukraine since 25.06.2018, the number of internally displaced persons in Ukraine is 1512755people. 18 higher educational institutions were forced to move to other cities due to the armed conflict in the Luhansk and Donetsk regions. In general, almost 40,000 of students and 3.5 thousand of academic staff moved outside the occupied territories [1].

The overall trend in Ukraine is toward continued human development improvements, but with quite a lot of catching up to do: Ukraine ranks $88^{\text {th }}$ out of 189 countries for which the HDI is calculated - which however puts the country in the high human development category [2]. The average rate of life expectancy in Ukraine is 71.4 years [3]. That's why scientists should focus on the leading ageing factors in modern living conditions among the youth. Thus, the research on biological age of youth is extremely topical, since economic and social future of the whole country depends on health of young people.

\section{Literature review}

Biological age is a set of rates which shows the body's condition of a particular person according to the average rates of people of the same age, era, nationality, geographical and economic living conditions [4].
So, biological age is a characteristic of any variable with age process, or a biomarker. There are groups of these processes and elements, which vary with their peculiarities, and therefore have certain names:

- chronological age reflects the ageing of the body and its systems averagely for a population, provides standard average death probabilities and life expectancy, a fact-based rate, connected only with the course of time and is expressed in absolute physical units of time;

- physiological age reflects the age dynamics of physiological and functional reserves, the person's ability to function. Some of these processes may have only a minor influence on the life expectancy, but determine the quality of life. Only certain processes can directly affect the life expectancy. Physiological age may substantially change due to exercising. While estimating the physiological age, it is preferable to consider the person's muscular work capacity rate, cognitive activity and emotional profile;

- pathological age reflects time dynamics and intensity of diseases and pre-illness conditions of a person, which affect the life expectancy. The characteristic of pathological age determines the specificity of treatment and prophylaxis [5].

Conventional diagnostics methods are needed to observe the processes of human ageing and take measures to increase the active work capacity in time. 
Biological age is a real degree of body's ageing, connected with certain vital activity rates of a person, and it can be measured. The research on these rates will allow us to study the tendencies of body's ageing [6].

The most important consequences of ageing processes include a shorter period of future life (higher probability of death), dysfunction of the most important vital functions and narrowing of the adaptation diapason, development of unhealthy conditions. Two signs are enough to reflect the ageing specificity: it's connection to the chronological age and its destructiveness. The duration of future life is the absolute measure of body's vital capacity (the amount of health). Estimation of the vital capacity is possible, when time from the examination moment to natural death of a person is predicted due to informative parameters [7]. In other words, the duration of future life is health capacity (in case of perfect and stable conditions).

Test sets of different difficulty levels are used to determine the biological age. The logical scheme of ageing estimation includes further stages:

1) estimation of the given individual's actual biological age (according to clinical and physiological rates);

2) estimation of the given individual's proper biological age (according to their chronological age);

3 ) comparison of actual and proper values (for how many years the examined outruns or stays behind their peers according to the ageing tempo).

The received estimation is relative, the starting point is a population standard, which is average value of ageing in a certain chronological age for a certain population. Such approach allows us to arrange individuals of one chronological age according to the degree of "age exhaustion" and therefore their health capacity [8].

The task of establishing the actual (biological) age is important for the whole gerontology.

Biological age is a concept that reflects the degree of morphological and physiological development of the organism. The introduction of the concept of "biological age" is explained by the fact that the calendar (passport, chronological) age is not a sufficient criterion for the state of health and working capacity of an aging person. As a criterion of aging, the biological age of a person depends on various positive and negative factors, such as physical exertion, the level of psycho-emotional stress, lifestyle and the state of the environment. These factors can lead to both an increase and a decrease in the rate of aging and the biological age [9].

Currently there are various approaches to determine the biological age using metabolic and physiological rates. Of course, it is impossible to measure all determining rates in one system, but it is unnecessary while estimating the biological age. Most physiological and biochemical rates are regulated according to stability of the internal environment and don't undergo substantial changes. So, establishing the biological age and regular deviances the number of rates may be not so big. Practically single figures can be used to determine the biological age. Sets of diagnostic tests are most widely used in clinical practice. The number of needed figures can vary from 3 to 37 . Sets of tests better characterize the homeostasis state of person's major body systems, which change with age, and allow us to provide more precise estimation of the biological age, rather that any other single test [4].

Chronological age is one of the most important risk factors for adverse clinical outcome. Still, two individuals at the same chronological age could have different biological aging states, leading to different individual risk profiles. Capturing this individual variance could constitute an even more powerful predictor, enhancing prediction in age-related morbidity. Applying a nonlinear regression technique, authors constructed a metabolomics measurement for the biological age, the metabolic age score; validated the score in two large independent population-based samples by revealing its significant associations with the chronological age and age-related clinical phenotypes as well as its independent predictive value for survival over approximately 13 years of follow-up. Furthermore, the metabolic age score was prognostic for a weight loss in a sample of individuals, who underwent bariatric surgery. Authors conclude that the metabolic age score is an informative measurement of the biological age with possible applications in personalized medicine [10].

Besides, one must consider all difficulties with estimation of reference values in old people and corresponding difficulties with evaluation of individual laboratory rates.

Different sets of signs are used to determine the biological age, which can be divided into further groups:

1. External signs of ageing;

2. Anthropological rates;

3. Physiological functions at rest;

4. Psychological and neuropsychic rates;

5. Physical load tests;

6. Biochemical and clinical rates.

All named groups of signs almost in any combination are used by different schools to estimate the biological age. The number of rates varies. It should be mentioned that the problem of optimal rates list for biological age estimation is still unsolved.

Such rates system should objectively reflect condition of different body structures and functional systems and suit further requirements:

- to reflect functional and/or anatomic state of an organ, system, metabolic processes, regulatory mechanisms;

- to change during a period from sexual maturity to deep old age (it changes substantially with age);

- to have definite correspondence with the chronological age;

- individual variation of rates shouldn't exceed the rates of its average value with age during a period of 5 years;

- to be technically performed by individuals of any age;

- to be able to be easily evaluated;

- to be reliable and easily reproduced during second studies, providing stable and comparative results;

- not to be the cause of death [11].

Leading biologists and clinicians, interested in aging, convened to discuss biomarkers of aging. The goals were to come to a consensus, construct an agenda for a future research, and make appropriate recommendations 
to policy makers and the public-at-large. While there was not a total agreement on all issues, they addressed a number of questions, among them whether biomarkers can be identified and used to measure the physiological age of any individual within the population, given emerging information about aging and new technological advances. The hurdles to establishing informative biomarkers include the biological variation between individuals that makes generalizations difficult; the overlapping of aging and disease processes; uncertainty regarding benign versus pathogenic age-related changes; the point at which a process begins to do damage to the organism, and, if so, when does it occur; and when to distinguish a critical damage from a noncritical damage [12].

\section{The aim and objectives of the research.}

The object of our study is to evaluate the biological health of students with the internally displaced status within 2-4 years from the date of evacuation from uncontrolled territories.

The aim of the study is to determine the degree and rate of aging of the body of students, to determine the leading factors of aging and the subsequent design of preventive measures.

Tasks of the research:

1. To study the problem's stage according to scientific sources data.

2. To make a poll on "Health self-evaluation".

3 . To estimate the biological age of the examined.

4. To determine the proper age of the examined.

5. To compare the biological, passport and proper age of students.

6. To evaluate the contradiction.

7. To evaluate body ageing tempos.

8. To determine the correlation factor between studying rates and students' biological age.

9. To develop recommendations on reducing the contradiction.

\section{Materials and methods}

Methods and organizing of the research:

1. Scientific publications analysis.

2. Polling.

3. Establishing the arterial pressure under Korotkov's method.

4. Ozeretskyi's test (static balancing on one leg). timation [8].

5. V. P. Voitenko's method for biological age es-

6. Mathematical statistics methods.

106 students of Vasyl' Stus Donetsk National University took part in the research, who belong to the major group and are relatively healthy during the research.

After working with literature, we found methods, based on indicators that are highly likely to correlate with age. This is the formula of the famous Ukrainian gerontologist V. P.Voitenko, which is actively used today [13, 14]. We were interested in easy, accessible and safe ones for mass application. We chose a method which allows us to estimate the biological age with the help of informative and simple tests that do not require special equipment. The biological age can be determined using the formula:

$B A$ male $=27.0+0.22 * S A P-0.15 * B R+0.72 * S E H Q$ $-0.15 * S B$

$B A$ female $=1.46+0.42 * A P P+0.25 * B W+0.70 * S E H Q-$ $-0.14 * S B$,

where BA - biological age;

BW - body weight, $\mathrm{kg}$;

SAP - systolic arterial pressure, $\mathrm{mm} \mathrm{Hg}$;

APP - arterial pulse pressure, $\mathrm{mm} \mathrm{Hg}$.;

SB - statistical balancing on the right leg, sec;

$\mathrm{BR}$ - breath retention, sec;

SEHQ - self-evaluation of the health of the questionnaire, point.

These formulas are suggested to determine the proper biological age (PBA) of the population standard:

$P B A=0.629 * C A+18.6$ - for males;

$P B A=0.581 * C A+17.3$ - for females,

where $\mathrm{CA}$ is the chronological age.

According to the $\mathrm{BA}^{\prime}$ formula, the indicated parameters were determined by the following methods:

- Systolic blood pressure (SBP) is measured using the standard method on the right hand, 3 times with 5-minute interval. The smallest result is taken into account.

- Arterial pulse (AP) is difference between systolic and diastolic pressure.

- Breath-holding at inhale is determined using the standard method.

- Stasis is calculated in seconds, standing with closed eyes on one leg (left for the right-handed and right for the left-handed), the other one must be flexed, the hands are put down along the torso. Test is carried out 3 times with 5 -second interval without previous training. This method uses the result of three attempts, where a person stayed longer.

The subjective health evaluation (SHE) is performed with the help of a questionnaire:

1. Is headache bothering you?

2. Do you state that you started waking up easily due to any noise?

3. Is pain in the region of the heart disturbing you? worsened?

4. Do you think that in recent years your eyesight worsened?

5. Do you think that in recent years your hearing

6. Do you try to drink only boiled water?

7. Do people younger than you offer you a seat in public transport?

8. Is joint pain bothering you?

9. Do you visit beaches?

10. Does weather affect your mood?

11. Do you have times, when you cannot sleep because of anxiety?

12. Is constipation disturbing you?

13. Do you think that now you are as hardworking as earlier? 
14. Is pain in the region of the liver disturbing you?

15. Do you faint?

16. Do you think that it's harder to concentrate than earlier?

17. Does worse memory or forgetfulness disturb you?

18. Do you have a feeling of burning, stitching or formication in different regions of your body?

19. Do you have times, when you feel excited, happy?

20. Is tingling bothering you?

21. Do you have any of these medicines in your house medicine chest: nitroglycerine, heart drops?

22. Do you have leg swelling?

23. Do you have to refuse from some dishes?

24. Do you experience short breath while walking

fast?

25 . Do you have to drink any mineral water due to treatment?

26. Do you experience pain in the lumbar region.

27. Is unpleasant taste in your mouth bothering you? easily?

28. Can you say that you can start crying really

29. How do you evaluate your health state? [8].

There are possible answers "yes" (+) or "no" (-) for 28 questions. Negative answers are "yes" for questions No. 1-8, 10-12, 18, 20-28 and answers "no" for questions No. $9,13,19$. There are such possible answers for question 29 as "well", "satisfactory", "bad", "very bad". Two last answers are considered to be negative. After filling in the questionnaire, the general amount of negative answers is calculated; this number is used in the biological age estimation formula. After filling in the formula with all test results and making arithmetic calculations, we get the student's biological age.

According to the method of correspondence estimation between the biological and the chronological age, the received individual biological age value should be compared with the proper biological age (PBA), which is the average population standard of ageing tempo. As a result, we can determine the increased of reduced students' ageing tempo according to the average rate for people with the same chronological age. If the person's age is higher than the population's, the difference between $\mathrm{BA}$ and $\mathrm{PBA}>0$, if it is lower, $\mathrm{BA}-\mathrm{PBA}<0$, and if it is the same as the population's average, then BAPBA $=0$. A program, called "STATISTICA", was used to process the results.

\section{Research results}

We surveyed 106 students of the Vasyl' Stus Donetsk National University (the University was moved to
Vinnytsia in 2014 due to the occupation of Donetsk city). We got $95 \%$ of the complaints on the health condition (on the scale of health self-evaluation). In a separate group we studied the biological age of students, immigrants from Donetsk and Lugansk regions.

We divided students into certain groups:

Group 1: 25 male students, who live in the Vinnytsia region constantly.

Group 2: 33 male students, who were evacuated from the military conflict area.

Group 3: 25 female students, who live in the Vinnytsia region constantly.

Group 4: 33 female students, who were evacuated from the military conflict area.

After the research was carried out, it was estimated that the biological age of group 1 is 37.6 years, which is 17.1 years higher than the chronological one (20.5 years) (Table 1). The average age of evacuated from the military conflict area students (group 2) is 41.3 years, which is 19.5 years higher than their passport age. The proper biological age of group 1 is 31.1 years, and group 2 is 32.3 years. It should be determined, which the examined rates are most closely connected to the biological age to influence it. Correlation coefficients are calculated through the Pearson's method (program called "STATISTICA"). The highest rating of displaced students is the static balance $(-0.74)$ (According to the Chaddock scale, these data indicate a high inverse correlation coefficient $(\mathrm{r}=0.7-0.9)$ (the smaller second person can balance on the leg, the greater his biological age) [15]. Health self-evaluation takes the second place, which mostly depends on harmful habits, moving activity (0.63). This show the noticeable direct correlation (according to the Chaddock scale, the noticeable direct correlation ( $\mathrm{r}=0.5-0.7)$. It was found, that the biological age of local students depends on the time of balancing on one leg with closed eyes $-0.78(\mathrm{r}=0.7-0.9)$, as well as the high inverse correlation, found in internally displaced students (males).

Analyzing the received results, it was determined, that both groups 3 and 4 (group 3: 25 female students, who live constantly in the Vinnytsia region, group 4: 33 female students, who were evacuated from the military conflict area) have the insignificantly increased biological age. The biological age of local girls is 29.2 years and of the dislocated is 25.8 years. The proper biological age for both groups is 29 years. The correlative connection was determined through the static balance -0.71 , it shows a high inverse correlation $(\mathrm{r}=0.7-0.9)$ and health self-evaluation 0.39 , according to the Chaddock scale, noticeable direct correlation $(\mathrm{r}=0.3-0.5)$.

AP and pulse didn't show even medium correlative connection, though their impact on the physical health is quite significant.

Table 1

Comparative characteristics of the biological and chronological age of internally displaced students and locals ( $\mathrm{n}=106$ )

\begin{tabular}{|l|c|c|c|c|}
\hline & $\begin{array}{c}\text { Chronological } \\
\text { (passport) age, years }\end{array}$ & $\begin{array}{c}\text { Biological age, } \\
\text { years }\end{array}$ & $\begin{array}{c}\text { Difference, } \\
\text { years }\end{array}$ & Difference, $\%$ \\
\hline Male & $20.5 \pm 1.5$ & $37.6 \pm 7.2$ & 17.1 & 83.4 \\
\hline Internally displaced persons-male & $21.8 \pm 2.0$ & $41.3 \pm 8.1$ & 19.5 & 89.4 \\
\hline Female & $20 \pm 2.0$ & $29.2 \pm 2.4$ & 9.2 & 46 \\
\hline Internally displaced persons-female & $20 \pm 2.0$ & $25.8 \pm 1.5$ & 5.8 & 29 \\
\hline
\end{tabular}


According to the correspondence estimation method between BA and CA, the increased rate of aging of male students was noticed. Group 1 have the increased ageing tempo, and group 2 have the strongly increased rate of aging. Groups 3 and 4 have the normal rate of aging.

So, only $9 \%$ of internally displaced students (male) have the normal aging rate, 45,5\% have the increased and strongly increased aging rate. But local students are also aging fast. Normal aging rates are set in 16 $\%$ of students, increased in $32 \%$, and strongly increased aging rate in $52 \%$ of students (Table 2).

Much better results were obtained, when we examined the rate of aging of female students. We did not find signs of the increased aging rate in internally displaced female students. Their aging rate, conversely, is within normal limits. 39,4 \% of internally displaced students (female) have the slowed-down aging rate and 60,6 $\%$ have the normal aging rate. We have not found any case of increased aging rate among internally displaced female students. Among local female students $16 \%$ have the slowed-down aging rate, $48 \%$ - normally, $24 \%$ - increased and $12 \%$ - strongly increased aging rate (Table $3)$.

Table 2

Comparative characteristics of the aging rate of internally displaced students and locals (male)

\begin{tabular}{|c|c|c|c|c|c|c|}
\hline $\begin{array}{c}\text { Functional } \\
\text { class }\end{array}$ & Difference, years & rate of aging & Internally displaced students & \multicolumn{2}{c|}{ Locals students } \\
\cline { 3 - 7 } & & & Number & $\%$ & Number & $\%$ \\
\hline I & from -15 to -9 years & abruptly slowed-down & 0 & 0 & 0 & 0 \\
\hline II & from -8.9 to -3 years & slowed-down & 0 & 0 & 0 & 0 \\
\hline III & from -2.9 to $+2,9$ & BA = PA & 3 & 9 & 4 & 16 \\
\hline IY & from +3 to $+8,9$ & Increased & 15 & 45.5 & 8 & 32 \\
\hline Y & from +9 to +15 & strongly increased & 15 & 45.5 & 13 & 52 \\
\hline
\end{tabular}

Table 3

Comparative characteristics of the aging rate of forced internally displaced students and locals (female)

\begin{tabular}{|c|c|c|c|c|c|c|}
\hline \multirow{2}{*}{$\begin{array}{c}\text { Functional } \\
\text { class }\end{array}$} & Difference, years & rate of aging & Internally displaced students & \multicolumn{2}{c|}{ Local students } \\
\cline { 3 - 7 } & & & Number & $\%$ & Number & $\%$ \\
\hline I & from -15 to -9 years & abruptly slowed-down & 0 & 0 & 0 & 0 \\
\hline II & from -8.9 to -3 years & slowed-down & 13 & 39.4 & 4 & 16 \\
\hline III & from -2.9 to +2.9 & BA = PA & 20 & 60.6 & 12 & 48 \\
\hline IY & from +3 to +8.9 & Increased & 0 & 0 & 6 & 24 \\
\hline Y & from +9 to +15 & strongly increased & 0 & 0 & 3 & 12 \\
\hline
\end{tabular}

According to the subjective health assessment questionnaire, the health status and signs of premature aging were established in 1 and 2 groups. $55 \%$ of students, living in Vinnitsa, rate their health status as good, $40 \%$ as satisfactory and $5 \%$ as poor. The survey showed that young men of different biological ages have different health assessments. In $40 \%$ of the respondents there were complaints about headache, in $22 \%$ - pain in the heart area, $17 \%$ reported dizziness. $33 \%$ of the internally displaced students (male) rate their health status as good, $47 \%$ as satisfactory and $10 \%$ as poor. In the analysis of questionnaires of temporarily displaced persons, an increase in complaints of headache $(45 \%)$ and pain in the heart area (25\%) was found, $15 \%$ of persons noted severe falling asleep.

Among the internally displaced female students $60 \%$ said, that the weather affects their mood, and $41 \%$ have leg swelling sometimes. So, among the local female students - same, $53 \%$ said, that the weather affects their mood. And $56 \%$ have short breath while walking fast.

\section{Research discussion}

We have found the increase in biological age and the increased rate of aging in male students. However, the female students' biological age and aging rate remain within normal limits. Particularly important is the fact that the biological age and aging rate of internally displaced and local students are not significantly different. In addition, the rate of aging of internally displaced female students is even lower. The obtained data on the bi- ological age and aging rates of male and female are consistent with the opinion of gerontologists that women live longer by 6-8 years and age more slowly. The calculation of the biological age in students showed that in male it exceeds $17.1-19.5$ years and in female 5.8-9.2 years.

About $50 \%$ of Vinnytsia students have the strongly increased aging rate. Almost $74 \%$ of male students had the strongly increased aging rate and $50.9 \%$ of female students (Kharkiv region) [16]. In the Poltava region, $84 \%$ of male students have the strongly increased rate of aging [17]. In the Lviv region, the strongly increased rate of aging was observed in 79.16 male students and $40.32 \%$ of female students [18]. Researchers reported the strongly increased rate of aging among Donetsk region students (62.6 $\%)$. The results of our study of the rate of aging of female students are consistent with the data, obtained by Kalinkina O.M. et al., who set the strongly increased rate of aging among female students in the Donetsk region (12.7\%) [19]. Interesting data on the strongly increased rate of aging of female students were established by Zaporizhzhia researchers $(88.9 \%)$, in our study - only $12 \%$ [20]. Thus, the data on biological age and the rate of aging of students in different regions of Ukraine are different. The pace of aging is influenced by lifestyle, social factors, motor activity, and the state of the environment [21]. To determine the leading factors in the increased rate of student aging, we need to examine the following indicators. In addition, it is advisable to analyze the changes in the rate of aging of young people in different regions of Ukraine over the last 
5-15 years (as external and internal factors of aging have been actively changing in these years).

However, the slower pace of aging of internally displaced students (female) is noteworthy. The results of the study suggest that displacement leads to the mobilization of adaptation mechanisms. However, this situation can lead to premature consumption of internal reserves and exhaustion of the body. A possible reason for the slow speed of aging in college students is their more active involvement in social life and they lead a healthier lifestyle. Analyzing and identifying the leading factors that influence students' aging rates will enable them to create comprehensive programs to prevent and reduce aging.

\section{Conclusions}

1. The internally displaced persons-male have the increased aging rate.

2. Students, who did not withstand the evacuation after-effects, have the increased aging rate. It is necessary to find out the cause of this phenomenon.
3. The females aging rate does not progress so much, but a correction of the psycho-emotional state is required in relation to a sufficiently high health selfevaluation index.

4. The identified biological age of the students can be used as a starting point for adjusting work functions and body systems.

5. Understanding the dynamics of changes in biological age and the mechanisms of premature aging can help in solving problems of engaging students in a healthy lifestyle and regulating the state of their bodies through physical culture and other methods.

6. In further research, it is planned to conduct a factor analysis and, based on it, to make a rational program for the purpose of reducing the biological age of students.

\section{Conflict of interest}

There is no conflict of interest

\section{References}

1. Ministry of Social Policy of Ukraine. Available at: https://www.msp.gov.ua/news/15512.html Last accessed: 28.06.2018

2. 2018 Human Development Indices and Indicators: 2018 Statistical Update. United Nations Development Programme. Available at: http://hdr.undp.org/sites/default/files/2018_human_development_statistical_update.pdf

3. Boryshuk, A. A., Olvinskaya, J. O. (2018). Demographic situation in Ukraine and its impact on the human development. Statistics - a tool of socio-economic research: a collection of scientific student works, 4 (1), 175-180.

4. Belozerova, L. M. (1999). Ontogeneticheskii metod opredeleniia biologicheskogo vozrasta cheloveka. Uspekhi gerontologii, 3, 108-112.

5. Kishkun, A. A. (2008). Biologicheskii vozrast i starenie: vozmozhnosti opredeleniia i puti korrekcii. Moscow: GEOTAR-Media, 976.

6. Boiarska, Z. A. (2018). Porivnialna kharakterystyka biolohichnohoviku ukrainskykh yunakiv u zalezhnosti vidkrainy prozhyvannia (Ukraina ta Polshcha). Journal Science Review, 3 (10), 21-23.

7. Voitenko, V. P. (1991). Zdorove zdorovykh (vvedenie v sanologiiu). Kyiv: Zdorove, 246.

8. Markina, L. D. (2001). Opredelenie biologicheskogo vozrasta cheloveka metodom V. P. Voitenko. Vladivostok: Vladivostokskii gos. med. un-t, 29.

9. Kasatkina, Y. I., Petrova, E. A. (2018). Comparative characteristics of methods on the determination of the biological age of a person by V .P. Voytenko and by A. G. Gorelkin. International Student Scientific Herald, 5. doi: http://doi.org/10.17513/msnv.18656

10. Hertel, J., Friedrich, N., Wittfeld, K., Pietzner, M., Budde, K., Van der Auwera, S. et. al. (2015). Measuring Biological Age via Metabonomics: The Metabolic Age Score. Journal of Proteome Research, 15 (2), 400-410. doi: http://doi.org/10.1021/acs.jproteome.5b00561

11. Johnson, T. E. (2006). Recent results: Biomarkers of aging. Experimental Gerontology, 41 (12), 1243-1246. doi: http://doi.org/10.1016/j.exger.2006.09.006

12. Butler, R. N., Sprott, R., Warner, H., Bland, J., Feuers, R., Forster, M. et. al. (2004). Aging: The Reality: Biomarkers of Aging: From Primitive Organisms to Humans. The Journals of Gerontology Series A: Biological Sciences and Medical Sciences, 59 (6), B560-B567. doi: http://doi.org/10.1093/gerona/59.6.b560

13. Gudkov, A. B., Demin, A. V., Dolgoborodova, A. A., Popova, O. N. (2018). Characteristics of rate of aging? Anxiety levels and quality of lifein older woman of the artic zone of Russia. Vestnik SurGU. Medicina, 4, 33-37.

14. Meleshkova, N. A., Shabanova, L. V. (2018). Biological age as a criterion the physical and mental state of university students. Psychology, Sports Science and Medicine. Saint Petersburg, 24-28.

15. Makarova, N. V., Trofimets, V. Y. (2002). Statistika v Excel. Moscow: Finansy i Statistika, 368.

16. Tserkovnaya, Ye. V., Nefedova, A. L., Osipov, V. N., Mirgorod, O. A. (2011). Biological age and aging rate of students with different levels of motor activity. Physical education of students, 1, 130-133.

17. Loshitska, T. I. (2010). Biological age and rates of senescence of organism of students. Pedagogy, psychology and medbiolog. problems of physical education and sports, 7, 51-53.

18. Leontyeva, S. R., Dutka, R. Ya. (2016). Biolohichnyi vik ta tempy starinnia studentiv. Bukovinian Medical Herald, 3, 107-109.

19. Kalinkina, O. M. (2007). The study of the possibility of using the biological age index to determine the impact of the environment on human health. Environmental protection and rational use of natural resources. Donetsk, 134-135.

20. Gureeva, A. M., Petrova, G. M., Kushnir, G. I. (2017). Vliianie zaniatii fizicheskim vospitaniem na biologicheskii i dvigatelnii vozrast studentok. Visnik Zaporizkogo nacionalnogo universitetu. Fizichne vikhovannia ta sport, 1, $26-34$.

21. Korobeynikov, G. V. (2010). Biological mechanisms of aging and motor activity of human. Physical activity health and sport, 2, 3-13.

Received date 12.11.2019

Accepted date 10.12.2019

Published date 30.12.2019

Zoryna Boiarska, PhD, Associate Professor, Department of Biophysics and Physiology, Vasyl' Stus Donetsk National University, 600-richya str., 21, Vinnitsa, Ukraine, 21021, E-mail: z.boiarska@gmail.com

Olga Dotsenko, PhD, Associate Professor, Head of Department, Department of Biophysics and Physiology,Vasyl' Stus Donetsk National University, 600-richya str., 21, Vinnitsa, Ukraine, 21021

E-mail: dots_don@ukr.net 